\title{
密集住宅地の「住戸群」における路地と隙間の役割に関する研究 A STUDY ON ROLES OF THE ALLEY AND GAP SPACE BETWEEN BUILDINGS IN GROUPS OF HOUSES IN DENSELY BUILT-UP AREAS
}

\author{
金 栄 爽*2, 高 橋 鷹志*1 \\ Youngseok KIM and Takashi TAKAHASHI
}

\begin{abstract}
The purpose of this study is to make clear roles that are characteristic of the space and behaviour in the alley and gap space between buildings in Nezu Tokyo. As a result of analysis, we recognized the following indications for the planning priciples of housing.

Firstly, there exist grouped units of houses in densely built-up areas. Secondly, the alley and gap space have roles as buffer zones between houses, passing ways of district and ventilatilation as well as access of sunlight. Finally, they afford behaviours and places for household's goods promoting the interaction between residents, and generating characteristics of common space as well as private space.
\end{abstract}

Keywards: groups of houses, alley space, gap space between buildings,

communication in densly built-up areas,

住戸群, 路地, 隙間, 密集住宅地のコミュニケーション,

1 はじめに

\section{1 研究の問題意識と目的}

都市に相応しい居住形式を確立することは，現代日本 の重要な課題のひとつであり続けてきた。我が国の既成 市街地の住宅は, 高度成長期以後, 宅地が細分化し, 狭 小宅地での建て替えは，さらなる狭小住宅を生む過密の 再生産となってきた。そして狭小な敷地の中にありなが ら，多くの住宅はパビリオンタイプ(1) を踏襲している。 また, 高密集合住宅 (いわゆるマンション) は, 土地の 効率・資産価值などが優先され, 既成市街地における住 宅の形態・町の構造・生活環境の破壊など, 問題を生み 出すことが多く，未だ都市の居住形式として成熟したも のではない。このような状況に対して, ゼロロット方式 による中庭型集合住宅 (2)などの都市型居住形式の研究 ・提案が行われている。計画を巡るソフトに関してす， 地区計画助成, 共同化の融資制度などの法・条例の提案 ・実践が行われているが, 部分的な成果にとどまってい るのが現状である。本研究は既成の町がすっている建築 ・外部空間の維持調整や隣り近所の仕組みに注目し，こ
れまで形成されてきた集住環境の構造を生かした居住形 式の計画コンセプトを得ることを目的とした基礎的研究 として位置付けられる。

建物間の残余空間や狭い路地など，既成市街地に隙間 的空間が多いことはしばしば指摘される。これらはいま までの居住形式の原則からは，無駄かつ悪環境の原因と して否定的に扱われることが一般的であった。しかし， 隙間的空間が生み出す様々な視線・経路の抜け, 分節さ れた建築・外部空間のスケール，それを使いこなす居住 者の能動的な生活行動などがセットになって, 都市の集 住環境を成り立てせていることす無視できない事実であ る。

以上の認識をもとに, 本報では密集住宅地の路地と住 戸の形成・変遷構造を把握することにより，その地域を 漸進的・段階的に建て替えるときの居住形式の単位とな り得る住戸のかたまりとして「住戸群」(3)（図1）を 抽出し，「住戸群」を構成している路地や隙間の物理的 環境特性と，そこで行われる行動の実態の記述を通して， その役割を明らかにすることを目標としている。
*1 東京大学工学部建築学科 教授. 工博

*2 東京大学工学部建築学科 大学院生. 工修
Prof., Dept. of Architecture, Univ. of Tokyo, Dr. Eng. Graduate Student, Dept. of Architecture, Univ. of Tokyo. 


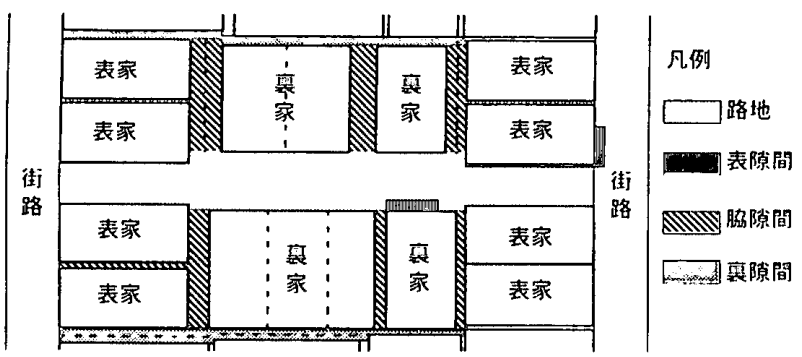

(1)路地：ここでの路地とは，道の幅が2.5m以下で車は通れないが，人は通るこ とのできる道, あるいは各性戸へのアプローチのための道を意味する。しかし， アパートの通路や2戸以下の住戸のアプローチのための道は除外する。また, 路地は私有地や私道であること，耐側の家の表が道に面していることなどが条 件である。しかしこの全てを满たさない路地るありうる。

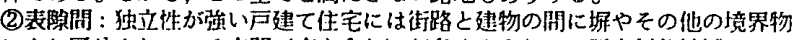
により区分されている空閒（庭を食む）が多くみら机る。研究刘象地域には， 街路に面する㜊が少なく，建物力゙境界線一环に建てられていたり，あるいは喔 根を被ってその空間加窒内化されているため，おまり侧が見られない。

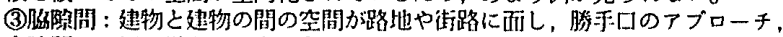

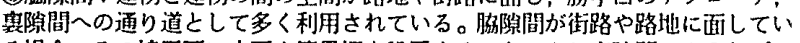
る場合，その境界面に枦や簡易塀を設置することにより寒淂間のようなブラ イベートな空間になっている場合すある。

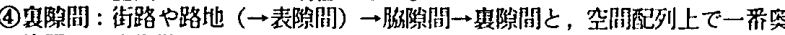

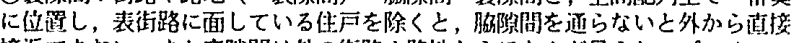

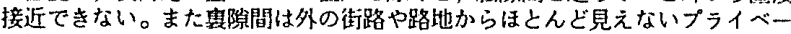
ト性が強い空間である。

図 1 「住戸群」の路地や腺間の概念

\section{2 既往研究との関連}

住戸まわり空間を巡る計画研究は，居住環境や生活の 質を向上や，あるいは実際のデザインへの応用において， かなりの成果をあげている。その主要なるのは以下のと おりである。

本報の視点のひとつである路地を中心とした住戸のか たまりを単位として取り上げた数少ない研究の中には， 小島裕一氏の研究 ${ }^{(4)}$ があるが, 袋小路の路上行為の把 握にとどまり，住戸のかたまりの仕組みを明らかにする
までには至っていない。住宅地の住戸まわり空間に関し ては，視覚的・心理的に落ち着いた環境を実現する条件 としての住戸と住戸の間の個体距離の研究 ${ }^{(5)}$ ，住み手 が主観的に感じる意識と個体距離との関係を解明しょう とした研究 ${ }^{(6)}$ ，また住戸と住戸の間の熱環境状態や住 戸内外の境界領域が住生活に持つ意味を考察した個体域 の研究 (7) などがあり，住戸間の環境のあり方を解明す るための重要な研究である。なお, 既成市街地の路地に 対して，近隣関係や住環境の仕組みを解明することによ り共生価值生成の構造を明らかにした研究 ${ }^{(8)}$ ，利用実 態を通して路地の領域性やコミュニティのかかわりに対 する新しい概念を明確化した研究 ${ }^{(9)}$ などでは，居住者 が自律的に，あるいは能動的に使いこなしている状況が 解明され，計画の概念を提供する研究として価值は高い。 その他，特に東京や大阪の既成市街地を中心として路地 での近隣関係・使われ方・生活行為や領域などの視点か ら，その実態が把握されている(10)。しかし，路地とい う空間の存在による町の構造の特徵，あるいはそれを介 した隣りとの関係や生活行動における役割を論じた研究 は，少ないのが現状である。特に，密集住宅地の建物の 更新や建て替えなどによって生まれる住戸と住戸ゆ間の 空間である隙間の役割を肯定的に把握している研究は見 あたらない。それとは逆に，密集住宅地の環境悪化の一 因として，路地や隙間が取りあげられることす多い。本 報はその現状を認識しつつす路地や隙間が密集住宅地の 環境を支えている役割に光を当てることを意図している。

\section{3 研究の方法}

路地や隙間が密集住宅地の居住環境の質に寄与してい

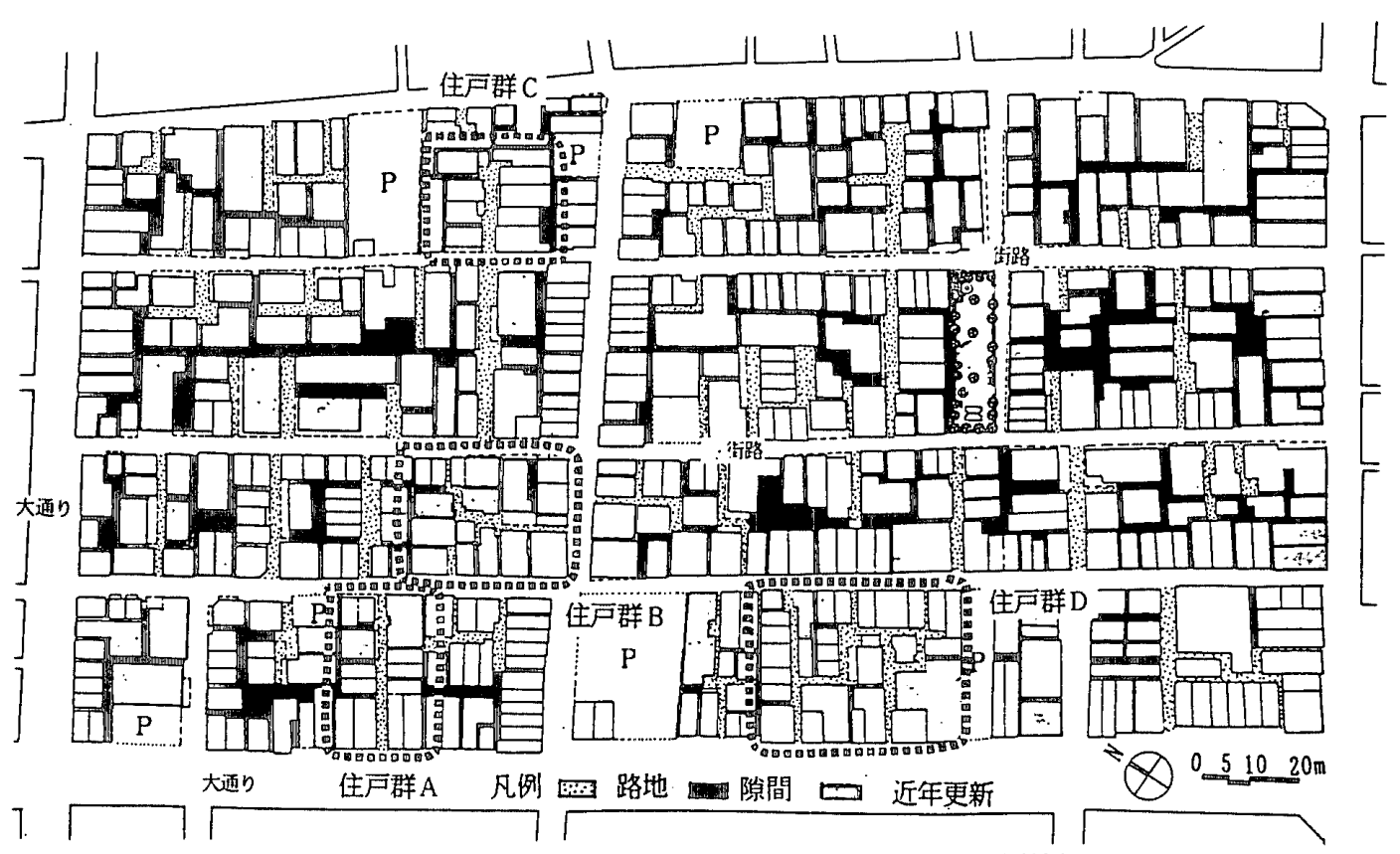

図2 研究対象地域の隙間と路地の分布及び更新状況 
る実態を明らかにするため，具体的な研究は 3 つの段階 に分けて進めた。

(1)「住戸群」の抽出 : 日本の都市には路地を介した長 屋・アパートのような都市居住タイプが存在し，その住 環境は住戸まわりの路地や隙間により支えられている。 その集合の仕組み（住戸群の構成）はこれからの居住形 式あり方を考察するに当たって継承に值する要素を含ん でいると考えられる。そこで, 現在の町をつくっている 住戸のかたまりを観察し，路地や隙間と住戸との関係か らその単位となっている「住戸群」の抽出を試みた。そ の類型の中から路地の特徵により 4 つの「住戸群」を対 象とし（図 2），住戸のかたまりの形態だけでなく，住 戸へのアプローチや生活の実態調查により集住生活にお ける相互関係を明らかにする。それを基づき，「住戸群」 の路地や隙間の存在と生活行動の関係について以下の考 察を進める。

(2)路地亡隙間の存在：「住戸群」には住戸の周囲に自 然に，あるいは止むを得ず発生した所有・境界・機能の 曖昧な路地や隙間が存在する。これらは見えない所有境 界線を持った私有地であるが，近隣の住民に開放され， 共有されている。そうして住戸内部の環境や機能を補完 するなど, 密集住宅地の空間構成の中では欠かせない役 割を果たしているすのあある。一方，放置され，ゴミ捨 て場になっていたり，保全に何らの効用むない，好まし くない路地や隙間も存在している。そこで, 路地や隙間 の役割を読み取るため, 路地や隙間の形態的特徵, 地域 の中での路地や隙間の分布状況，「住戸群」の居住環境 （風・日照・視線）維持状況などの実態を観察, 実測, 記述し，特徴を分析する。

(3)路地之隙間での行動 : 現代都市居住者の隣り近所の 関係は，浅くなりつつあると一般的にいわれてはいるが, ここでは「住戸群」を成立させている路地や隙間を挟ん で，様々な行動が行われていることに着目する。そこで， 行われているコミュニケーションや行動（単独行動や住 民の相互作用）がどのようなきっかけでどこの場所で行 われているかの実態をとらえ, その仕組みの特徴を記述 し，路地と隙間の役割を明らかにする。

\section{2 調查の概要}

東京の都心に近い密集住宅地である根津（図3）は， 18世紀初めに建立された根津神社の門前町として始まり， その後発展と衰退を繰り返しながら, 関東大震災・第二 次世界大戦にむ焼け残った数少ない密集住宅地のひとつ である。多くの建て替えを経た現在です古い下見板張り の木造家屋が所々に残っている。また，国道・都道など の計画道路が少なく, 大通りと街路 (幅 $4 \mathrm{~m}$ と6 $\mathrm{m}$ ) で区画 された中に私道である路地が残っている(11)。このよう

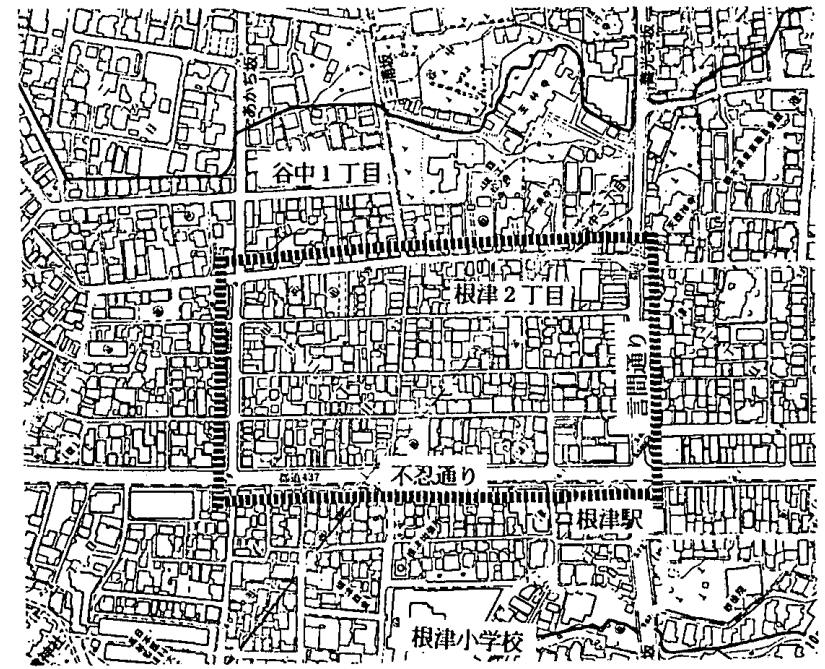

図3 研究対象地域の位置図

\section{表 1 調查の概要}

\begin{tabular}{|c|c|c|c|c|c|}
\hline 二次处笅目視調榅 & \multicolumn{5}{|l|}{ 1992. $6.23(火) \sim 25($ 水 $)$} \\
\hline 二次夾観自視調焦 & 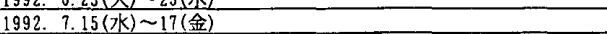 & \multirow{2}{*}{\multicolumn{4}{|c|}{1992.11 .9 (水) 11 (金) }} \\
\hline 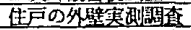 & 1992. 7.15(木本) 17(金) & & & & \\
\hline 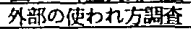 & \multicolumn{5}{|l|}{$1992.11 .16($ 水 $) \sim 18$ (金) } \\
\hline 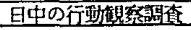 & \multicolumn{5}{|c|}{ 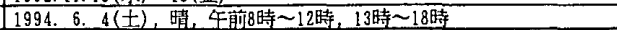 } \\
\hline & & 住声群A & 住戸群 B & 住戸群C & 住言群D \\
\hline 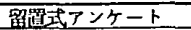 & 1992.10 .30 (金) & 16 户 & $19 \bar{F}$ & 12 户 & $23 \bar{E}$ \\
\hline 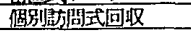 & $1992.11 .6($ 金 $) \sim 9$ (月) & $12(75 \%)$ & $15(79 \%)$ & $9(75 \%)$ & $18(78 \%)$ \\
\hline ヒフリング調䉓 & $1992.11 .10(火) \sim 16$ (月) & $9 \vec{E}$ & 9户 & $6 \bar{F}$ & 15न \\
\hline
\end{tabular}

な根津の一区画を研究対象地域（図 2) として選定し， 以下の調查を行った（表 1 ）。

(1)研究対象地域に対して, 全ての路地や住戸のアプロ 一千状況, 住戸形式, 構造, 階数, 建て替元や更新状況 などの外観目視調查を通して，まず路地を介した住戸の 集合により住戸のかたまりを分類した。次に，1992年度 の地籍図を参考に，敷地割との関保を確認した上で「住 戸群」を抽出し，路地の形態が異なっている住戸群A〜 住戸群Dの 4 つを取り出し, 住戸まわりの実測調查をす とに平面図の作成を行った。(2) 4 つの住戸群での生活実 態や隣り近所との関係ついて, 留置式アンケート調查を 行い, その後補足調查として, 路地や隙間でのコミュニ ケーション状況に関するヒアリング調查を行った。(3)路 地や隙間においてあるそノや各場所の機能を把握するた めの使われ方調查を行った。(4)以上の調查の補足として， 路地や隙間の活用状況を知るために, 行動の種類・行動 の継続時間・回数などの日中行動観察調查（午前 8 時〜 12 時・午後 2 時〜 6 時）を行った。

\section{3 「住戸群」の把握とその特性}

\section{1 「住戸群」の抽出方法}

研究対象地域の敷地割りは，1912年の地籍図 ${ }^{\text {(12) }}{ }^{\text {(図 }}$ 4）を見ると，大通りに面する敷地は短冊の形が多く， 街路に面しては短冊敷地と大きな敷地が混じっている。 1992年の地籍図と比べると, 各敷地は，時代と共に分割 


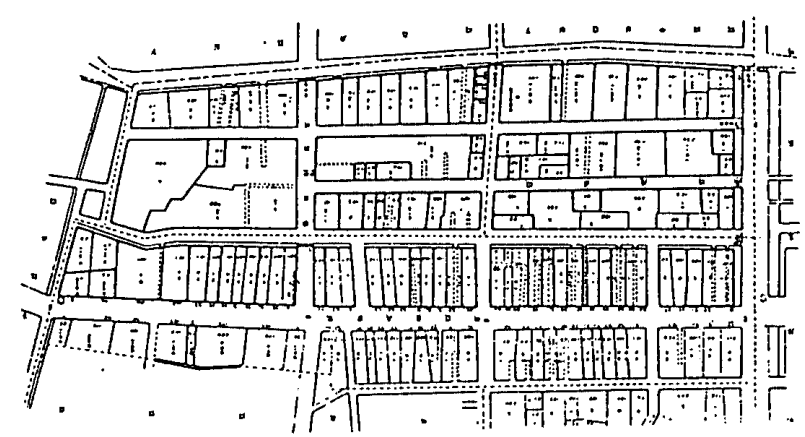

図4 研究対象地域の1912年の敷地割り

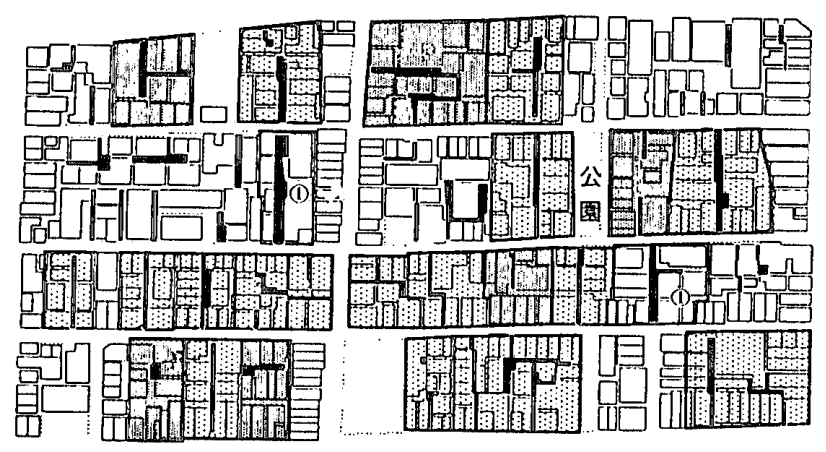

図 5 住戸の集合の分類と「住戸群」

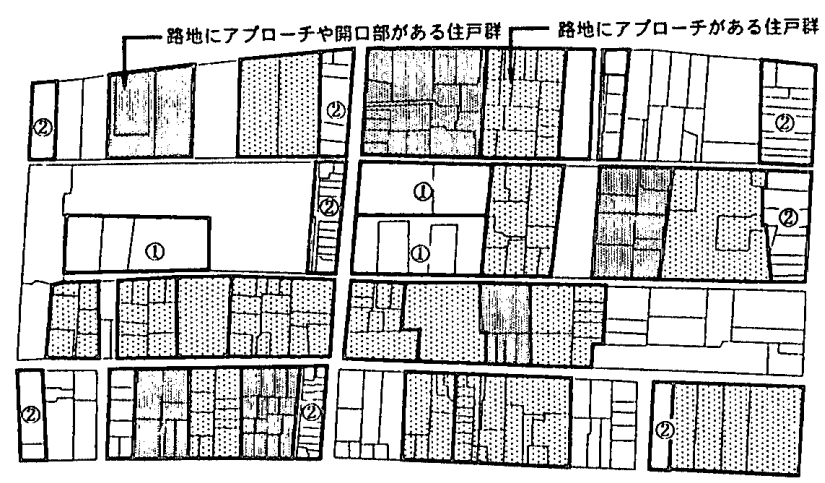

図6 1992年の地籍図の效地割りと「住戸群」

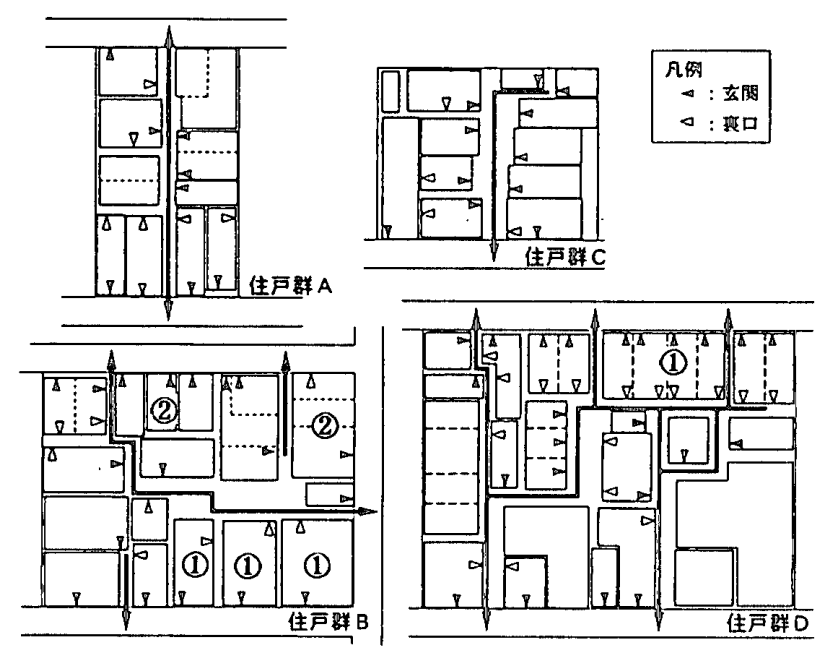

図7 住戸のアプローチと路地との関係
されるか，あるいは単一敷地として残されている。特に， 幅6街路に面している短冊敷地では，さらなる短冊への 分割が見られる。また，路地は短冊敷地の境界線に設け らることが多く，敷地の細分割や建物の建て替えにより， 昔からの路地がなくなっていることすある。

「住戸群」を抽出するため, 路地を介した住戸の配置 による住戸のかたまりを分類した図（図5）と，1992年 度の地籍図による敷地割り図（図6）の 2 つの図面を作 成した。図5によると, 同一の路地を玄関口や襄口（勝 手口）として利用している住戸の集合は 15 カ所ある。 また，同一路地にアプローチはないが，愙などの開口部 が路地や隙間に面している場合は 6 力所ある。図6で分 かるように，このような住戸の集合のほとんどは敷地割 りと一体となっており，これらを「住戸群」として抽出 する。抽出された「住戸群」の面積の範囲は約 $500 \sim 1$, $500 \mathrm{~m}^{2}$ である。

「住戸群」として抽出できなかった敷地は，以下のよ うな条件を備えている。(1)以前からの敖地割りが街路を 中心として横に長いため, 現在の敷地割りと住戸の配置 むそれに従っているすの（図5の(1)）。(2)街路に面して る短冊敷地に長屋を建ってて貸したままの敷地，占るい は敷地が分割されたすのがある（図5 の(2)）。(3)住戸の 配置は「住戸群」として成り立つが, 敷地割りは住戸の 配置と一体となっていない（図4の(1)），あるいは敷地 割りは「住戸群」として区分できるように見えるが，住 戸の配置は敷地割りと一体となっていないなどの理由で， 「住戸群」として抽出できなかったものである。

\section{2 「住戸群」の表と裹の連結}

抽出された「住戸群」の中から路地の形態により住戸 群 $\mathrm{A}$ 〜住戸群 $\mathrm{D}$ の 4 つを選び, アプローチ動線や空の向 きが路地に面していることにより起こる生活上の住戸の かたまり方を具体的に分析する。

住戸へのアプローチ（図7）㧼家（図1）が店や長 屋の場合, 表玄関以外に住戸の裹にある勝手口や隙間の 木戸を設けている例が多い。そこに至る道は表家の胁隙 間や路地を利用することがほとんどである。表家と裹家 との関係は, 住戸正面の方向が違うため, 住戸の蓜置上 の関わりが弱く, 表家の正面と囬家が分離されているが, 表家の裹口の動線が裹家との関係をつくりだしている場 合むある。その出入りによって表家と裹家の交流が生じ ることあある。また，表家の物干し台はほとんど裹にあ り，そこと䘚家の胁隙間の物干し台や空とが対面するこ とにより，表家と裹家との関係が生じることすある。例 えば，表家の裹が路地に面している住戸群 B と住戸群 D の一部の住戸では，「表の視線を避けるため裏の裹口を 主婦の専用の出入りとしてあ使っている」ということす インタピューから分かった（図７の(1)）。この場合, 表 
家の玄関が街路に面していてあ，玄関が路地に面してい る他の住戸との生活関係を持っことむある。このように 4 つの住戸群のほとんどの住戸は，少なくとも路地に玄 関か，裹口が設けられているが，街路に面している一部 の新筑アパートには街路に面して玄関があり，路地から アプローチできない（図7の(2)）。しかし，悹は路地あ るいは路地に接している隙間に面していることから通行 を介した強い生活関係はないむのの, 路地に面する住戸 と生活関係ができる可能性はもっている。

\section{34 つの住戸群の特性}

ここでは，4つの住戸群に対して，環境行動の様態や 路地や街路と住戸の関係における各住戸の玄関戸と空の 開放程度を中心にその特性を探る。また，物的諸元に関 しては表 2 に示す。

(1)住戸群A（直線路地）: 街路から向こうの街路まで 視線が通り，近隣の人々が通ることあ多い（表10）な ど，路地は外部に対して開放的である。しかし，住戸の 正面が路地に向けて開放的であった古い住戸はほとんど なくなっており，路地の真ん中にあるアパートの玄関戸 は路地に向けて閉鎖的である。

(2)住戸群B（折れ曲がり路地）：向こうの街路まで視 線は通らないが，歩いて抜けられる路地であるため，こ の路地に住んでいる人々だけが通り，街路に対して閉鎖 的である。街路に面している一部のアパート以外は，建 て替えされた戸建住宅の玄関戸は引き戸となっているた め，開放的である住戸が多い。

(3)住戸群C（行き止まり路地）：幅2.5mの路地待街路 から内部の様子が伺え開放的であるが, 通り抜けはでき ない。一番奥にある新筑の戸建住宅やアパート以外は， 古い住戸がまだ残っているため，路地に面する住戸の正 面む開放的である。

(4)住戸群 $\mathrm{D}$ (複数の路地が混在している) : 街路から 視線は通らないが, 近道として近所の人々も利用するこ とあしばしばあって，半開放的であると言える。全体的 に古い路地や住戸がほとんど残されている。街路に面し ては典型的な長屋が残っている。路地に面している住戸 あ長屋が多く，住戸の玄関口む開放的である。

\section{表 2 「住戸群」の物的諸元}

\begin{tabular}{|c|c|c|c|c|c|c|}
\hline & 住司群A & 隹官群B & 住言群C| & 任户群D & 平鸟 & \\
\hline 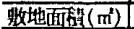 & 607.2 & $\frac{10}{1.088 .0}$ & 551.2 & $\frac{1.100 .2}{1.2}$ & & \\
\hline 建築而积 $\left(\mathrm{m}^{2}\right\rangle$ & 481.8 & 796.4 & 377.5 & 697.7 & & ハ \\
\hline 路地面些 $\left(\mathrm{m}^{2}\right)$ & 58.5 & 129.5 & 61.9 & 232.1 & & 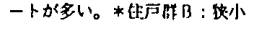 \\
\hline 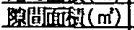 & 67.0 & 162.1 & 111.7 & 170.4 & & 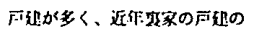 \\
\hline 延床栭稓 $\left(\mathrm{m}^{2}\right)$ & 760.9 & 1.534 .2 & 693.9 & 1.302 .6 & & 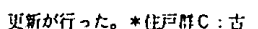 \\
\hline 建入目里(\%) & 75.8 & 73.2 & 68.5 & 63.4 & 70.2 & い辰星がり、近作戸建とアハ \\
\hline 容稆淁 (\%) & 147.0 & 141.0 & 125.9 & 118.4 & 133.1 & \\
\hline 路地淮 (\%) & 11.3 & 11.9 & 112 & 21.1 & $\overline{13.9}$ & ートの返新が行った。*仳声明 \\
\hline 闃率 (\%) & 12.9 & 14.9 & 20.3 & 15.5 & 15.9 & D：古いR、か多く、はとんど \\
\hline 世稓数 & 18 & 25 & 12 & 29 & & 这斩してふい。大迥りに面して、 \\
\hline 鱼住者数 & 36 & 62 & 28 & 52 & & \\
\hline 话 $(\Delta /$ & 592 & 516 & 508 & 563 & & 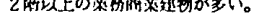 \\
\hline
\end{tabular}

\section{4 路地と隙間の存在による機能}

\section{1 路地之隙間の分類及び形態的特徵}

密集住宅地の各住戸は，住戸内部の空間だけで環境が 保持できずに，住戸に接した路地や隙間があって初めて 住宅としての機能が保たれることが多い。腺間はその機 能や位置により図 1 のように表隙間・枷隙間・裹隙間に 分類できる。その異なる特性や機能を表 3 に示す。また, 図 9 のようにセットバック・物干し台・境界塀・増築な どの断面形態や幅の違いも見られる。また，研究対象地 域の街路の幅は4mあるいは6m，建物の高さ $6 \sim 7 \mathrm{~m}$ が多く， 路地は幅 1〜2.5mで, 高さは街路とほぼ同じである（図 $10 ）$ 。隙間の 1 階部分の幅は $10 \mathrm{~cm}$ から $120 \mathrm{~cm}$ までさま ざまであり，幅によって機能む異なっている（表4）。

4 つの住戸群の居住者に対するアンケート調査から， 隙間によって遮音性や遮断性が確保され，プライバシー

\section{表 3 路地や隙間の形態的特性と機能}

\begin{tabular}{|c|c|c|c|}
\hline & 平面的特性 & 断面的特性 & 空間の機能 \\
\hline $\begin{array}{l}\text { 路 } \\
\text { 地 }\end{array}$ & $\begin{array}{l}\text { 住戸へのアブローチ路 } \\
\text { 幅は2.5m以下 } \\
\text { 私有地や私道である } \\
\text { アバートのわき道值除外 }\end{array}$ & $\begin{array}{l}\text { セットバック物干し台 } \\
\text { とび出し物干し台 } \\
\text { セットバクに增築 } \\
\text { 正面の住戸と金面壁か稙立 }\end{array}$ & 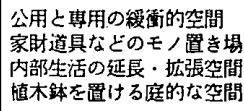 \\
\hline $\begin{array}{l}\text { 表 } \\
\text { 腺 } \\
\text { 間 }\end{array}$ & 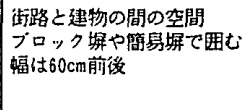 & 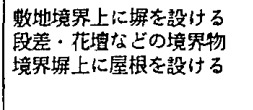 & 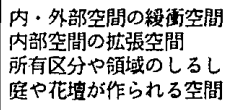 \\
\hline $\begin{array}{l}\text { 脇 } \\
\text { 傹 } \\
\text { 間 }\end{array}$ & 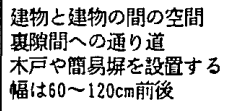 & 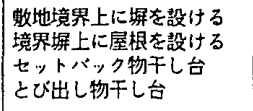 & 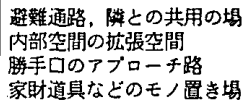 \\
\hline $\begin{array}{l}\text { 翼 } \\
\text { 祭 } \\
\text { 間 }\end{array}$ & 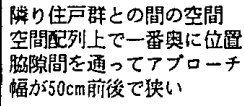 & 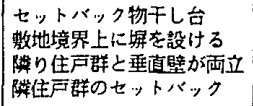 & 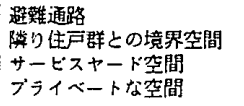 \\
\hline
\end{tabular}

\section{表4 蝠による腺間の機能}

\begin{tabular}{|c|c|c|c|c|}
\hline 幅10ca以下 & 堛 $10 \mathrm{~cm} \sim 30 \mathrm{~cm}$ 以下 & 蝠 $30 \mathrm{cs} \sim 60 \mathrm{caD}$ 以下 & 蝠 $60 \mathrm{c} \sim 100 \mathrm{cmER}$ & 叠100 ca以上 \\
\hline 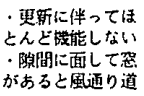 & 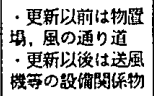 & 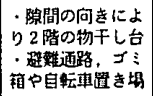 & 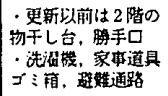 & 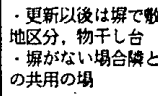 \\
\hline
\end{tabular}

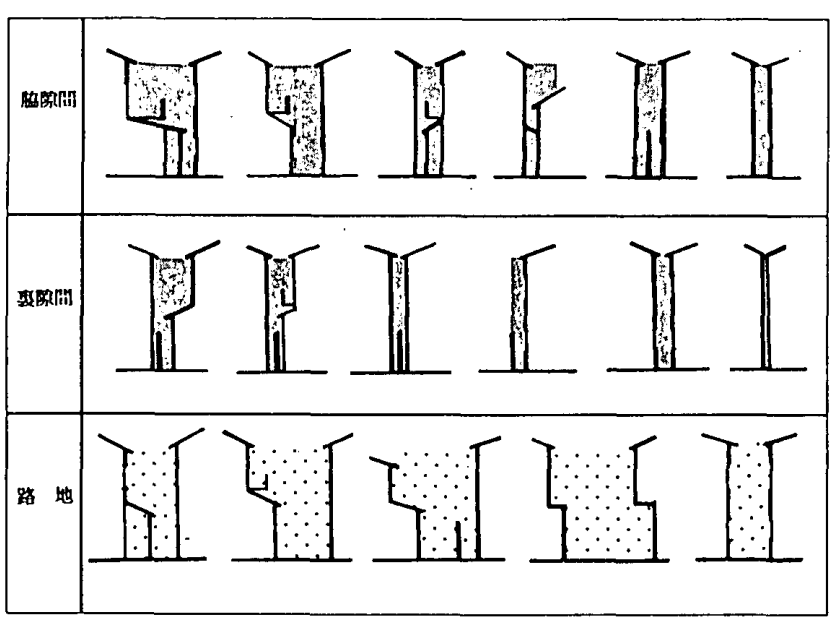

図9係間や路地の断面形態 

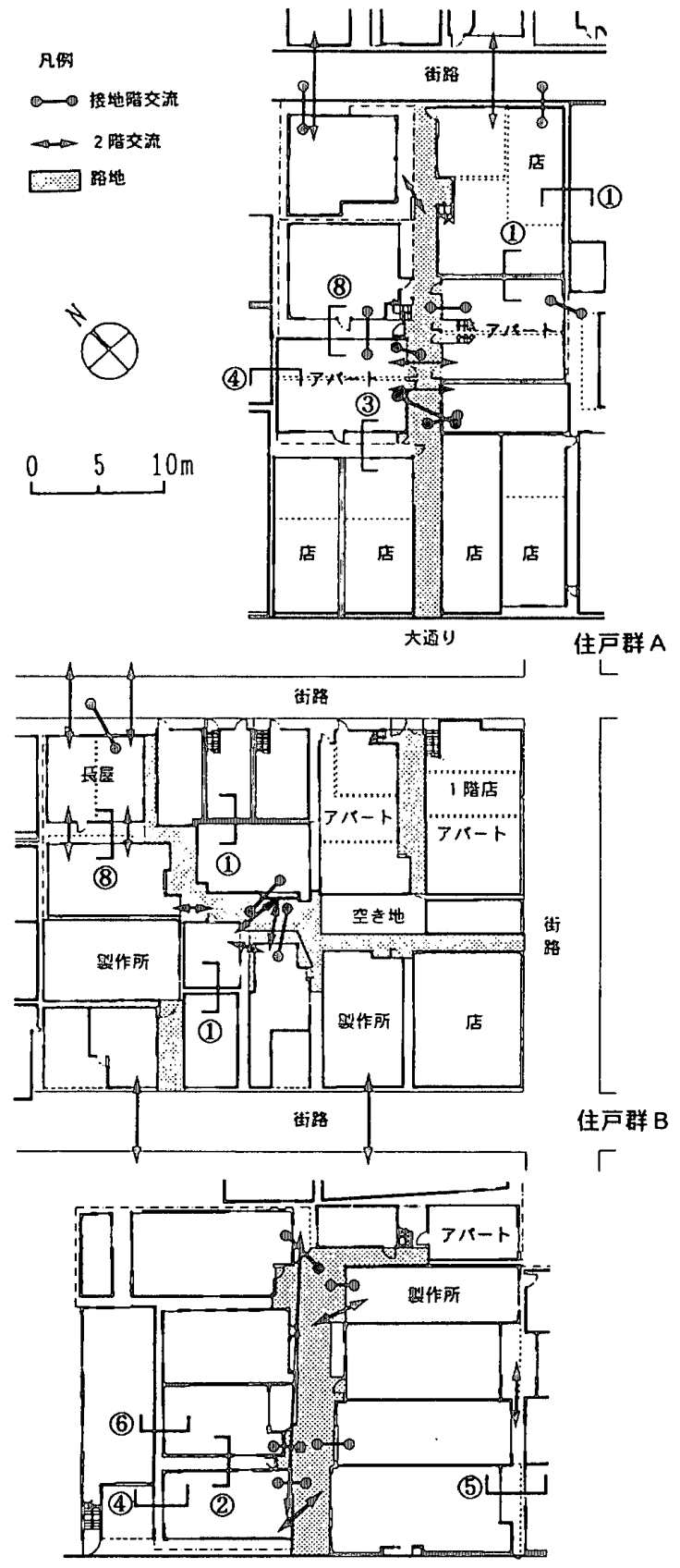

街路

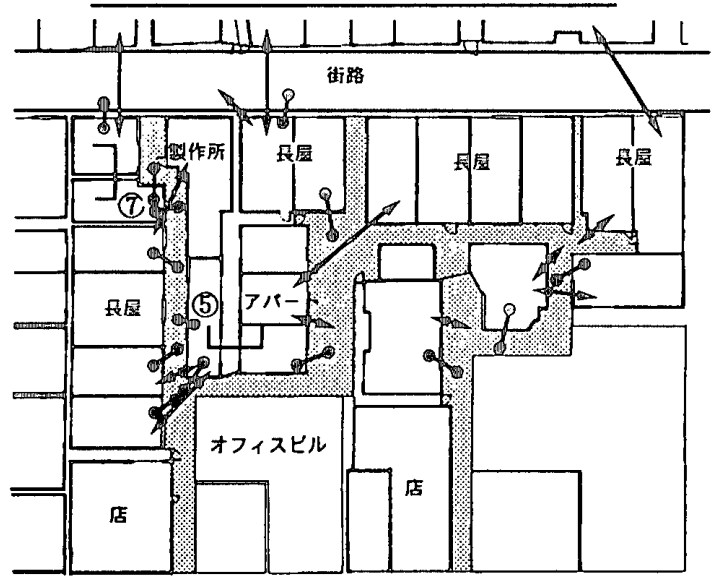

大通り

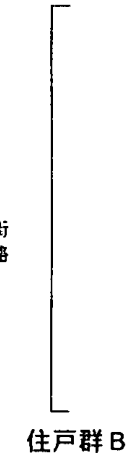

$\Gamma$
住戸群 C

住戸群口

図8「住戸群」の平面及びコミュニケーションの場所

が維持されていることが分か った。アパートや長屋では, 隣の音や気配が気になること が生活の不満として指摘され ている(表5)。一方, ほん のわずかな隙間を介した住戸 どうしでは，その不満はある 程度避けられる。隙間の発生 要因は，施工・民法・所有な どにあ関係があって, 図8の 各住戸の配置で分かるように 更新を行う場合にす，幅 $10 \mathrm{~cm}$ くらいの隙間がしばしば発生 する(図8の(1)）。

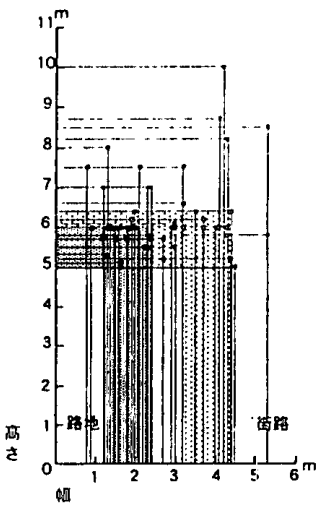

図 100 街路や路地の 幅高さ比

\section{表 5 隣の住戸に対する不満内容}

\begin{tabular}{|c|c|c|c|c|c|}
\hline 隣に対して爻になること & $\begin{array}{l}7 n^{\circ}-\uparrow \\
\text { 長屋 } \\
\end{array}$ & \begin{tabular}{|c|}
$\bar{F}$ \\
建 \\
\end{tabular} & 䑀に気をつけていること & \begin{tabular}{|l|}
$n^{\circ}-1$ \\
長展 \\
\end{tabular} & $\begin{array}{l}-\overline{\bar{F}} \\
\mathrm{Be} \tau\end{array}$ \\
\hline 「マの意がうるさい & 1 & & 夜大密な愠を出さない & 5 & \\
\hline 夜大きさ音を出す & & 1 & 苳は静かにする & 2 & \\
\hline 固りの卢の站㘦うるさい & & 2 & 騒且に気をつけろ & 1 & \\
\hline 上階の雨トイの音がうるさい & 1 & & ピフ/を彈くとき空を閉める & & \\
\hline \multirow[t]{4}{*}{ たまに大きな声が固にえる } & & 2 & Tレやラシオの音再に気をつける & 3 & \\
\hline & & & 洗台中排水音に氮をつける & 2 & \\
\hline & & & 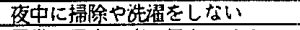 & 2 & \\
\hline & & & 子供の足音や声に気をつける & 1 & \\
\hline
\end{tabular}

\section{2 地域の中での路地と隙間}

研究対象地域は, 幅 $6 \mathrm{~m}$ と $4 \mathrm{~m}$ の公共の街路と, 私道であ る路地により街区が分けられている。アンケートに応じ た 55 戸のうち 7 戸が裹隙間を避難通路として考えてい る。路地には，幅が2mくらいの開放的な路地（図 111 の (1)）と，街路を渡って連続している路地（図1 1 の(2) があり，後者は抜けられる直線路地で行き止まり路地に 比べると，人通りが多く半公的になっている。本来の路 地は，住戸群内部の人だけの半私的ものであったが，最 近は敷地区分や境界を表す段差や木戸などがなく，路地 に面している住戸の外壁（空や玄関戸）が閉鎖的になっ ていることから，近隣の人々が通ることも多くなり，半 公的性格が強くなっている。例えば，住戸群 $\mathrm{A} の$ 路地で は，外部の人が通る 8 回のうち 6 回が住戸群外の近隣の 人々であることが観察された。

このように, 街区に壁を形成している街区型集合住宅 や大規模の建物が中心となる街区に比べ，路地や隙間を 持つ街区は人・視線・自然環境（風, 太陽, 雨) が通り 抜け，開放感を与え，狭い敷地の中で表玄関以外のアク セスを可能にし，空間や生活の領域を広げるのに役立っ ている。

\section{3「住戸群」での居住環境の維持}

「住戸群」の居住環境は路地や隙間に依存せざるを得 ないことが多く, 表家は表の街路と裹の胁隙間に, 裹家 


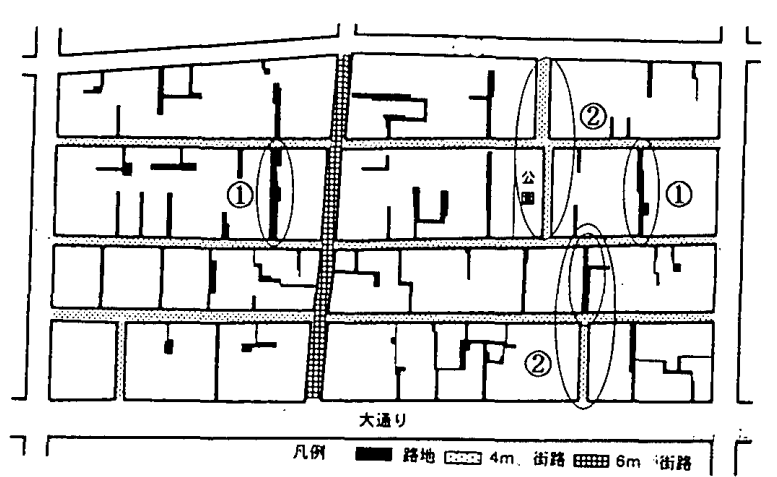

図1 1 街路や路地のネットワーク
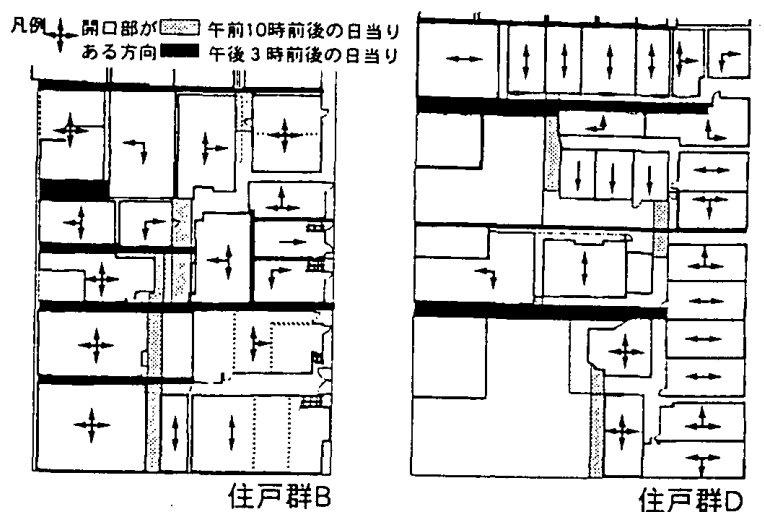

住戸群D

図 12 路地や隙間に日が当たる範囲

は正面の路地と脇隙間や稟隙間に依存していることすあ る。陁間は更新や建て替えの際に，なくなったり，逆に 広く取ったり，空をっくらないこともある。例えば，住 戸群しの哀家は裹庭によって環境を維持していたが，建 物の新築により消隇し, 現在は裹庭が 3 軒にしか残って いない（図8の(2)）。裹家がアパートとして建て替えら れた住戸群 A の場合, 裹陌間に面する開口部をなくし， 脇隙間を広く取っている例むある（図8の(3)）。また， 建物の改装の際には, 日が当たる可能性が低い北西方向 の裹隙間には悹を閉鎖したり（図8の(4)），あるいは室 内化すること（図8の(5) などが見られる。また，物を 置いたり，開口部に家具を置くなど，裏隙間が使われて いないことすある(図8 の(6)）。

一方，密集住宅地では短い時間であ開口部に日が当た ることは生活上大きな意味を持つ。2 方向に路地や隙間 の筋があれば，少なくとも 1 日 2 回そこを抜けて，奥深 いところまで日が当たっている（図１2）。また，路地 や隙間はそこを抜ける風の流れができるので，幅が $10 \mathrm{~cm}$ 以下の狭い隙間であってす，風通しがあり，ほとんどク ーラーを使わない例するる（図8の(7)）。
表 6 会話が行われている場所

\begin{tabular}{|c|c|c|c|c|c|}
\hline 路地 & $39 \bar{F}$ & 自宅内 & 16羿 & 自分相手供に家の中 & $6 \bar{\Xi}$ \\
\hline 自宅呦 & 20 当 & 相主宅 & $13 \bar{F}$ & 直分は家の中にいて外の人と & $9 \overline{\nexists ् F}$ \\
\hline 相手宅網 & 13 常 & 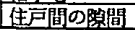 & $\frac{15}{1 \overline{7}}$ & 目分は外にいて家の中の人之 & $8 \vec{\nexists}$ \\
\hline
\end{tabular}

\section{表 7 視線の交流と挨拶・会話の相関}

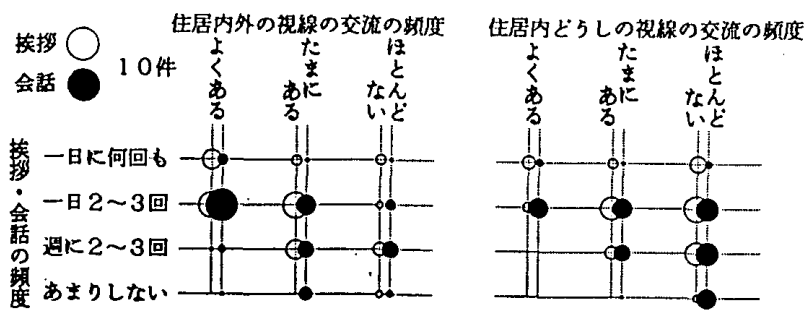

\section{表 8 視線の交流と挨拶・会話の発展}

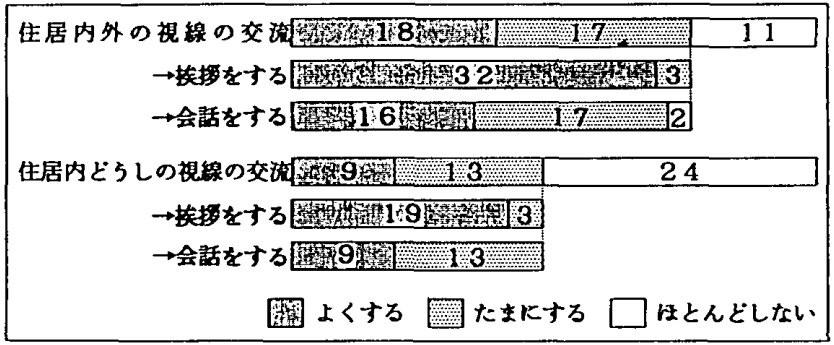

5 路地と隙間での行動による特徵

5.1 コミュニケーションが行われる場所

アンケート調查によると，視線の交流・挨拶・会話な どのコミュニケーションが行われる場所として路地が多 く, 具体的には家の前（玄関のある住戸）が使われてい る（表6）。例えば，玄関や空が向かい合っている路地 では，お互いがその空間を挟んで会話をする一方，視線 の交流も行っている。なお，玄関先や路地に面する部屋 と，その前の路地にいる人との会話が行われることああ る。隙間を挟んで住戸内にいる人どうしの視線の交流や 会話は避けられるのに対して，隙間を挟んでの住戸内部 と隣の物干し台や階段などとの会話あある程度存在して おり（表7），住戸外で出会ったときのみの交流を補い， コミュニケーションのきっかけとなっている。また，コ ミュニケーションが行われる場所（図 8) は, 以下のよ うに2つに分けて考えられる。

(1) 1 階における交流：路地に面してる開口部は通行する 人の視線にさらされ，そ扎を防御する遮蔽物があること が多いため，住戸内と外の交流は少ない。木戸や塀によ り路地加らの視線を遮断されている住戸群 $\mathrm{A}$ の幅 $2 \mathrm{~m} く ら$ いの隙間では，挨拶以上の立ち話や洗濯しながら話しを することすあった ${ }^{(13)}$ (図8の8)。また，袋小路にな っている住戸群Cでは, 住戸前の通行人がごくわずかの 顔見知りに限られており，1階での住戸内と外で交流が 
行われている。

(2) 2 階における交流 : 路地や隙間の 2 階部分をセットバ ックさせ, 物千し台が多く設けられている。作業時刻が 一致しやすい物干しをしながら視線の交流や会話が生じ やすい。話者どうしが幅 $4 \mathrm{~m}$ の街路を挟む場合，挨拶や短 い会話になるが, $2 \mathrm{~m}$ くいの路地や隙間の場合はもう少 し長く会話する傾向もある。また物干し台では，2 階ど うしの交流以外に, 路地や街路を通る人との視線があっ て，挨拶や短い会話をすることすある。

路地や隙間にモノをおく以外に，モノと関連する行動 を通して，挨拶・会話が誘発されることす少なくない。 例えば，路地や隙間で行われている「洗濯」「家事作業」 「物干し」「植木の手入れ」「しつらい行動」がそのき っかけとなってコミュニケーションが誘発される。実際, 視線が合うことから挨拸や会話が発生する可能性は高く， 視線の交流を行っていると答えた人のほとんどは, 挨拶 や会話をしている（表 8 ）。例えば，住戸群 Dの長屋に 住んでいるDさんは「普段は裏隙間の木戸を閉めておく が，洗濯をしている時は木戸を開けておく。同じ時間に ちょうど路地を通る人と視線があって，挨拶や会話が行 われ，場合によっては通る人を家のなかまで誘ってお茶 を飲むこともある」と言っている。

\section{2 行動のきっかけになる要因}

路地や隙間にはモノをおく以外に，モノと関連する行 動や独自の行動が見られる（表 9）。このような行動を 通して, 隣り近所との付き合いが生まれることああると 考えられる。ここでは, アンケートやヒアリング調查か ら得られた結果を補足し, 前述の行動が発生する状況と その要因を把握するため, 日中行動観察調查を通して, 具体的に考察する。

ゲールの屋外空間での活動の分類 (14)を参考に, 密集 住宅地の路地と隙間での行動を以下のように分類し，そ の特徴を述べる。

(1)「必要行動」：歩行と家事に分けて考えられる。歩行 はある目的を持って通ること。家への出入りのアプロー チに伴うことが多い。家事は普段住戸内部で行われる家 事 (洗濯・掃除・修理) が外の決まった場所で行われる こと。(2)「任意行動」：落着いて一時的に定留すること ができる場所での目的を特に持たない散策・鑑賞などの 行動。(3)「社会行動」：2 人以上の行動として会話や子 供の遊びなどであり歩行や家事, 任意行動で互いが接す るとき生ずる行動である。ゲールは，「任意活動や社会 活動が多いほど空間は活用され，活気ある空間である」 と述べている。

表 10 の行動の観察内容から分かるように，路地や隙 間での行動は, 歩行以外の必要行動である家事が多く行 われている。それから社会行動に発展する例す観察され
表9 路地や隙間においてあるモノと行動

\begin{tabular}{|c|c|c|}
\hline & 路地中榢問に图いておるそ， & 行かれている行娌 \\
\hline 路地 & 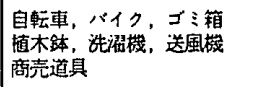 & 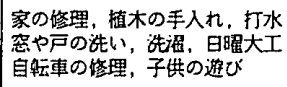 \\
\hline 胵袮間 & 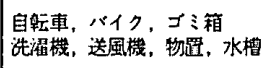 & 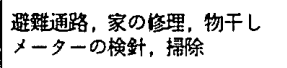 \\
\hline 的䟢間 & 筬笛な傢旁道具 & 避䧽通路，下水道の消毒・掃除 \\
\hline
\end{tabular}

表 10 路地での生活行動分類 *註：住戸群Aの場合

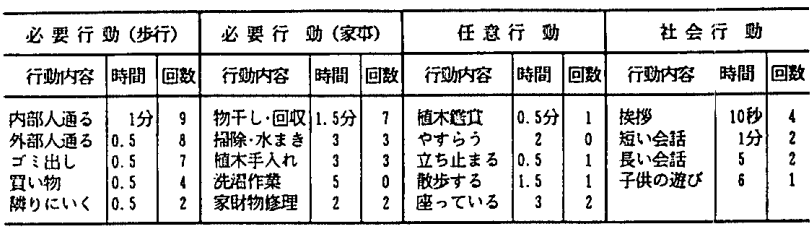

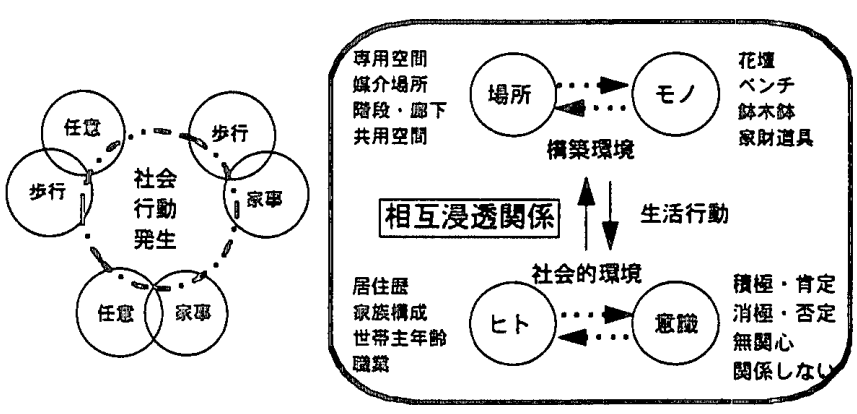

図13 社会行動の発生及び環境と行動の相互浸透関係

た（8例）。例えば，植木鉢に水をやっているAさん亡， 買い物に出かける途中のBdんと出会って，「暑いです ね」といいはじめて約 2 分くらい立ち話をする。その横 を近隣のCさんが通るが，挨拶むなく，立ち話中のBさ んは後ろ姿をしばらく見ながら話を続ける。また，2階

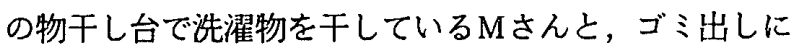
いく途中のNさんは視線があって，挨拶をする。外出中

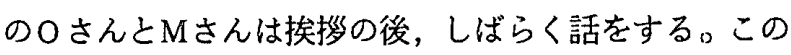
ように歩行・家事・任意の行動は, 行動が接する機会が 多いほど社会行動に至る可能性は高い（図13 の左）。 また, 行動の発生頻度は行動の種類・行われる時間の量 。回数とも関わっており, 行動が接する時間が少ない場 合, 社会行動が行われる可能性も低くなる。

行われる行動のきっかけとなる要因としては，「場所」 （物干し台・自分の家の隙間・玄関先など）と，おいて ある「モノ」（植木鉢・洗濯機・自転車など）があり， それを媒介に行動が生まれ，そこでの個別行動は社会行 動に進展することあある。従って, 社会行動が多く, 活 気ある路地としての質をアップさせるためには，「場所」 と「モノ」及び行動の主体である「ヒト」が互いに関係 を持つような仕組みが必要である。同じ条件の「場所」 と「モノ」があってあ, 居住歴・家族構成（老人や子供 の同居)・職業 (自宅での自営業) など，ヒトの属性別 


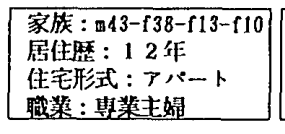

计路

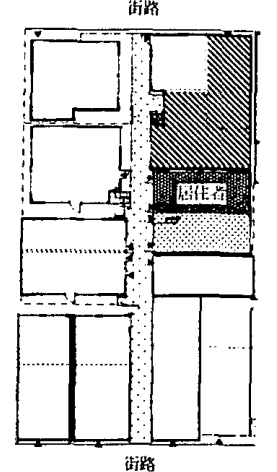

徒路

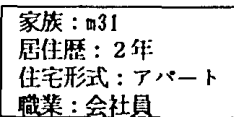

计此

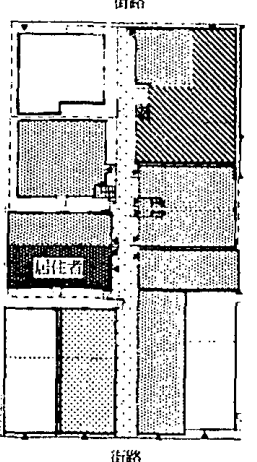

㨁路
家族: $\mathrm{f} 52-\mathrm{m} 26$

居住暦: 34 年

位宅形式 : 一豆建て

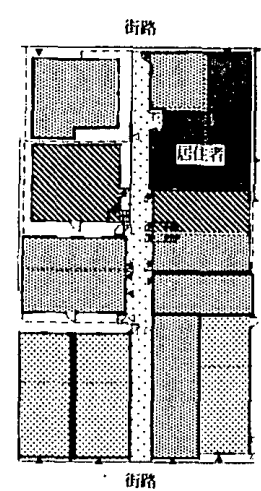

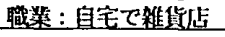

凡例

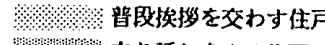

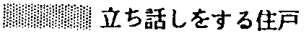

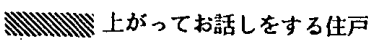

図14ヒトの属性により異なる近所付き合い

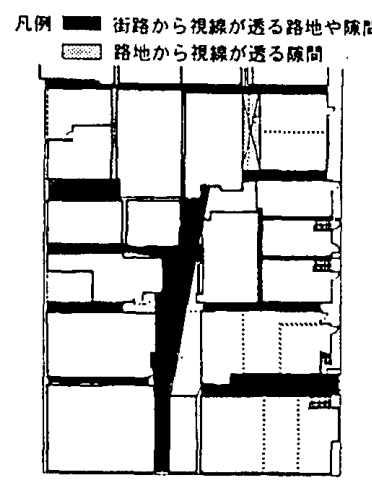

住戸群B

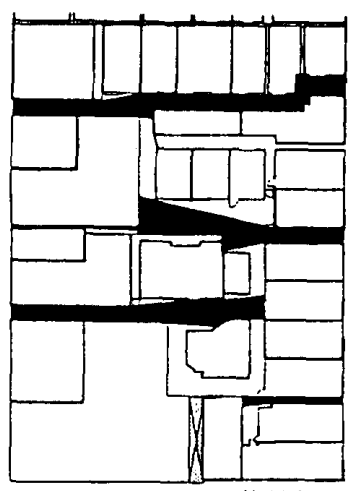

住戸群D

図15視線が通る路地や㩐間

に行われる行動の内容や頻度は違ってくることすある。 4 つの住戸群の居住者属性はすべて把握しているが，次 の報告にゆずるとして，今回はその一部を述べることと する。例えば，図14 の事例で分かるように，居住者の 属性により近所付き合いが異なっていることが分かる。

しかし，場合によっては 3 つの要因が揃っていても， 「ヒト」の参加意識や個人の価值観により社会行動の発 生の可能性は変わってくる。また，このような行動は， 物干し台での会話や玄関前の植木に水をやりしながらの 会話のように，ある時間帯に抢互いがある場所に出てい るとき生まれる。反面，上卜の意識や近隣関係，行われ る行動の時間差などによりお互いが辟けることすできる 隣り近所の付き合いが可能である。

結局，構築環境での「場所」や「モノ」によって生ず る生活行動は（特に社会行動），「ヒト」や「意識」に よる社会的環境との間の相互浸透関係により生まれる可 能性が高くなると言える(図13の右)。

\section{3 視線が透る路地や隙間と行動}

路地や隙間と行動との関係のもうひとつの観点として， 視線が透ることが考えられる。

研究対象地域は，塀で囲まれている住宅地とは違って， 各住戸の隙間がつながって街路から问こう側を垣間見る ことができ, 街路から各散地内部の隙間の一部む見られ る。住戸群の中に一歩入れば路地加らむ隙間を介して街 路が見えたり，隙間の内部が見られる（図15）。場合 によっては，枷腺間に木戸をつくることにより 1 階部分 は見えないが，2階部分が開いていることによって明る い向こう側が見られる。従って, 街路を歩く人です路地 亡隙間のなかには何が建てられているか，何が置いてあ るか，何が行われているかが全く伺われないわけではな い。また，実際そこから，「洗濯」「物干し」「修理」 などの行動が見える。

視線が通ることにより，街路を歩く人に開放感や活気 を感じさせるのに一役買っているとも言える。また，そ の路地や隙間での行動が, 同し路地に住む人以外の通り かかる人とのコミュニケーションのきっかけになること あある。逆にそれは，それらの行動をしながら住む人が 路地や街路を見ることができるということですある。そ こでの付き合いは，自分の意志により選択の余地がある。 事例は少ないが, 住戸群Dの路地や隙間において各々ひ とつづつ見られ，そこで挨拶や立ち話の可能性は高く， 実際に前述のDさんの例があげられる。

\section{6 まとめ}

以上の分析と考察を基に，本報のまとめを述べる。 (1)住戸のかたまりとして「住戸群」の抽出

まず，既存の町の中に存在している住戸のかたまりに 着目して, 路地や隙間によって支えられている住戸の配 置構造と，住戸の集合の基になる敷地割りの特性により， 「住戸群」が存在することを明らかにした。続いて，4 つの住戸群に対して，各住戸の向きや生活状況が路地に 向き合い，あるいは連結されていることにより建物だけ ではなく生活のまとまりる存在していることを，具体的 な分析により確認を行った。この結果「住戸群」が, 密 集住宅地の集住単位として成り立つ可能性が見えてきた。 しかし, 計画に生かすためには, 居住環境の自律性や隣 りの「住戸群」との明確な境界などの考察も必要であり， 今後の課題として残したい。 (2)路地と隙間の存在により読み取れた役割

a) 家と家の緩衙空間 : 家と家との間に場所と空気がある ことによって個々の家のプライバシーが得られることも あり，隙間の存在によって隣の音や振動などに対する遮

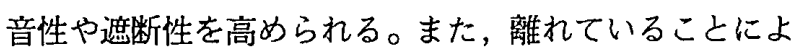


って自分の家の外壁が外から見ることができ，自分の家 の識別性を高められる。

b) 地域的インフラとしての路地空間 : 外部空間のネット ワークにすなり, 連続した路地は住戸の裹口のアプロー チや半公的な近隣の通り道として，道の選択性や避難通 路としてす利用される。

c)住戸の中に環境的効果をむたらす装置 : 路地や隙間が ひとつの筋をつくっていることは, 街路から視線が抜け ることはすちろん, 各住戸の通風効果を增すことと, 空 から間接光はむちろん直接光がそこへ流れ込む時間が出 来る。

しかし，居住者にとって逆にのぞかれたり，お互いの 近さを感じる，あるいは他人が勝手に入るなどの生活に 悪影響を与えることもある。

(3)路地と腺間での行動から読み取れた役割

a) コミュニケーションを誘発させる空間 : 路地や隙間が あることによって誘発されるコミュニケーションがある。 それは，次の行動へのきっかけにもなる。住戸の内部ど うしでは視線を避け合うルールがある一方で, どちらか が路地や隙間に出ることによってコンタクトが生じる場 合がある。

b) 行動発生のきっかけがつくられる空間 : 路地や隙間に おいてあるモノや物干し台を介した行動によって，その 上で路地や隙間の活気を増やす社会行動が発生すること あある。

c)自分と近隣が共有できる，あるいは選択できる空間 : 視線が通る路地や隙間に，洗濯や作業などのために出て いられる小さな自分の場を持つことは，近隣とのコミュ ニケーションを助ける。

居住者の生活の都市への拡張と, 居住者の私的領域へ の閉鎖的な生活の増大により，互いの関係の縮小や意識 あ弱くなりつつある中で，行動を誘発させるきっかけに なる路地と隙間の存在と，干涉されることなく自分の場 に自分のモ/をおけることは，充分ではないが，隣り近 所の付き合いの発生可能性を与えてくれる。また，人々 が出会う時間さえ増えれば，その可能性はむっと高くな ることが分かった。

しかし，「住戸群」の路地や隙間は，機能を果たして いない無関心に置き去りにされた空間，管理の行き届く 領域から離れた不快感や不安感を与える空間, 密集化に より過度の干渉が生じる空間などになりやすいという弊 害があることにす注意する必要がある。

以上の考察による, 密集住宅地における実態から導か れた「住戸群」での路地や隙間の役割は, 新しい居住形 式の計画においてす継承されるべき部分を含んでいると 考えられる。

\section{謝辞}

本研究をまとめるにあたり，貴重な助言を頂いた東京 大学工学部鈴木毅助手 - 教養学部横山ゆりか助手, 並び に集住研究会のメンバーの御協力を頂きました。記して 心から感謝の意を表します。

尚, 本研究は「財団法人住宅総合研究財団」の助成を 受けたあのである。記して感謝の意を表したい。

*林这

（1）庭付き独立住宅や既成市街地のマンションなどの配置において，一槽建 ての周緑にわずかな空間が残されるような屋教型配置を指す。 （小沢明：「バビリオンからゼロ・ロットへ」，住宅特集，pp125１26， 1992年 2月号)

（2）牧地の内部に中庭を囲む形式として，口字型・コ字型などがある。特に， 「協調ゼロロット中庭型ハウジングシステム」による中庭型集合住宅の 提案も見られる。（小沢明他：「新しい都市居住への提案」, pp111〜1 17，彰国社，1990年)

（3）路地及びそれに房状に取り付いた一団の住戸とその間の路地や䏚間で構 成されている空間單位，あるいは敷地割りと住户の集合がー体之なって いる單位を「住戸群」と名付ける。住戸群の建て替えは個別に行われる よりも2 户以上の多数の住户が部分的に行われる，最終的な加たまりと して成立する最小の集合単位，あるいは共同建て替えを行う際の基本峃 位である。また，都市居住形式における最小の果住生活の単位でもある。

（4）小島裕一：「住居倮合单位としての袋小路空間に関する研究」，日本建 築学会大会学術講演梗概集（東海）F，pp121～122，1985年10月

（5）仙田満他 2 名：「建築の個体距離仙関する研究!，日本建築学会計画事 論文倮, 423 号, pp41 48，1991年5月

（6）仙田満他 2名：「住み手の意識加らみた建策の個体距離」，日本建築学 会計画系諭文集， 435号，pp33〜 40，1992年5月

（7）エスベランサカロ他 2 名：「伝統的な住宅における個体域の瓄填特性と 社会行動了，日本建築学会計画系諭文集，460号，pp87 94，1934年6月

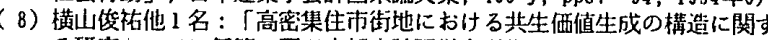
了研究」, 1990 年第25回日本都市計画学会学術研究論文集, pp211 216

（9）青不营次他 1 名：「開放的路地空間での領域化としてのあふ机出し」 日本建築学会計画棌論文集，449号，pp47～55，1993年7月

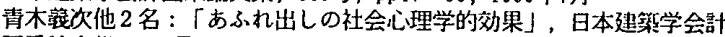
画棌調文集，457号，pp125１32，1994年3月

(10) 本研究の問題意棓に関連する路地を巡る研究として以下があげられる。 藤本焉太郎他 4 名：「高密度集住地区の研究No.3 (谷町の髟屋を対 象として）」一路地の解折一，日本建策学会大会学術講演挭概隼（近触） $F, p p 1675 \sim 1676 ， 1980$ 年9月

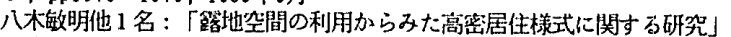
日本建筑学会大会学術講演梗概集 (北陸) E, pp1237 1238，1983年9月

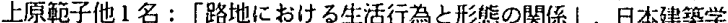

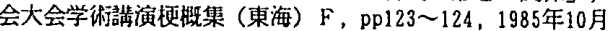

（11）研究対象地域は，前述した特徵以外に，実際の建べい率が70\%を超元， 庭がない戸建て住宅，小規模のマンションが混在する密集住宅地になり つつおる。また，都心に近いため若い新規居住者む多く住むようになっ て，定住層之流動層汃泿在しつつある。

（12）研究対象地域の数地割り関する疽料として，手に入れられる一番古い19 12年の地籍図を参考に元の敖地割りの状況を探ることは佂値があると考 えられる。(「地籍台帪・地籍地図 $1912 」 ，$ p169 柏残房)

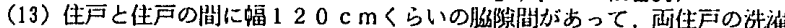
機や物干し台・勝手口が面している。その場を共有して様々な曰常行動 が行われている。この枷譩間は，特殊例ではあるが，今後の計匡におい て生かす可能性があると考えられる。

（14）公共空間で行われる屋外活動に関して，必要活動·任意活動·杜会活動 の3つにタイプに分けている。（J．ゲール：「屋外空間の生活とデザ イン」, pp15 21, 鹿島出版会, 1990年)

*参考文献

1）金栄函他 3 名：「住戸群としての路地の構造に関する研究」，目本建第 学会関東艾部研究報告集，1993年

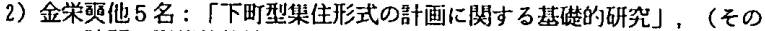
1 : 隙間の形貼的特性について），(その 2 : 隙問の特徽と使われ方に ついて），(その3：腺間でのコミュニケーションについて），日本建 筑学会学術峤演梗概集 (関東) E, pp121 126, 1993年

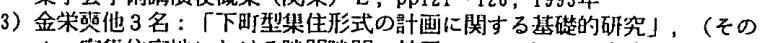
4 ：密集住宅地における腺間隙間の效用について），日本建築学会学術 譵演梗概集（関東）E，pp155 156，1994年

（1994年 7 月 10 日原稿受理，1994年12月27日採朋決定） 